\title{
Remembering Marley: A Portrayal of THE Reggae Superstar IN MARLON JaMes's A Brief History OF SEVEN KILLINGS
}

\begin{abstract}
The article reads Marlon James's A Brief History of Seven Killings (2014) as an example of a literary text functioning as a public memorial. For the Jamaican society, a cult figure whose image is well established in cultural memory and perpetuated through acts of remembrance is Bob Marley. Marlon James's A Brief History of Seven Killings, which revolves around an attempted assassination of Marley in December 1976 and its socio-political context, builds a composite picture of the singer, interweaving fragments of numerous interior monologues of the novel's characters-narrators. The scattered information passed to the reader via the opinions of diverse personae, shows Marley as a person, artist and symbol. James's book may be recognized as an agent of remembrance, implanting in its readers a certain vision of past events and Marley's legacy, especially if we recognize the text's strategies to transmit memories and, following Ann Rigney, view the novel as a "portable textual monument".
\end{abstract}

Keywords

Bob Marley; Marlon James; portable textual monument; reflexive narrative memorial; collective memory; cultural memory; Jamaica; novel

\section{Literature as an agent of remembrance}

Ever since the so-called "memory boom" (Whitehead 2009: 3; Berliner 2005: 197; Winter 2001: 53), which scholars locate in the last decades of the twentieth century (Huyssen 2000: 22), the role of literature as a vehicle for collective and cultural memory has been an important subject of academic discussion. 
Especially noteworthy in this respect is the work of German authors - Astrid Erll, Ansgar Nünning, and Renate Lachmann, who in their concern with literary issues broaden the scope of the by-now-canonical research on cultural memory of Jan and Aleida Assmann. Andreas Huyssen interprets the rise of memory studies as a reaction to technological development and the unprecedented pace at which new information is delivered and then quickly forgotten. Thus, in his understanding, a wish to remember stems both from a fear of forgetting and a human need to be more securely anchored in the changing world. He writes: "My hypothesis here is that we try to counteract this fear and danger of forgetting with survival strategies of public and private memorialization" (2000: 28). Survival strategies that keep the collective memory of a nation or an ethnic group alive may take the form of various social practices, including the creation and maintenance of numerous institutions of commemoration: re-enactments of historical events during anniversaries, museum and monument building, preservation of historical archives, special media broadcasts, and the publication of such works which perpetuate or forge shared memory and circulate preferred versions of the past.

Collective memory, first brought to public attention by the French sociologist Maurice Halbwachs and viewed today as "reconstruction of the past in the light of the present" (Coser 1992: 34), is not so much about remembering, and much more about acts and politics of remembrance. As Astrid Erll notes: "Versions of the past change with every recall, in accordance with the changed present situation. Individual and collective memories are never a mirror image of the past, but rather an expressive indication of the needs and interests of the person or group doing the remembering in the present" (2011: 8). In Halbwachs's understanding, such a construct retains from the past only those elements that are "capable of living in the consciousness of the groups keeping the memory alive" (2007: 140). Literature as a powerful medium and vehicle of memory which forges, circulates, and transforms the collective memory of a group of people plays a fundamental and multidimensional role in the construction of this group's cultural identity. The impact of literature as an agent of remembrance consists in creating collective memories while speaking of the past and making it familiar. However, since literature may offer plural perspectives, it not only fulfils the affirmativenormative function in the construction of identity but also, while exercising its immense capacity for subversion, proposes alternative views and visions. Texts not only circulate images of the past. Simultaneously, they enter into a dialogue with other texts or the politics of remembrance. Literature's potential to "destablise' memories by provocatively opening up cracks in the consensus" (Erll and Rigney 2006) is huge. How societies remember their past, how they preserve and shape memories of their heroes and idols, defines them as groups, forming the basis of their collective identity. Yet, since "cultural memory is not so much a reservoir in which images of the past are gradually deposited by some ongoing social process [but] [...] the historical product of cultural mnemotechniques and mnemotechnologies [...] through which shared images of the past are actively produced and circulated" (Rigney 2004: 366), it is worth looking at the role that 
a work of fiction may play in the formation of such images, becoming an item of a mnemotechnological cycle.

For the Jamaican society, a cult figure whose image is well established in cultural memory and perpetuated through acts of remembrance is Bob Marley - the reggae artist who became the first superstar of "The Third World." I would like to argue that Marlon James's novel A Brief History of Seven Killings (2014) may be treated as an act of remembrance. Applying the theory proposed by Astrid Erll in her article "Literature, film and the mediality of cultural memory" (2008), and drawing on Ann Rigney's concept of "portable textual monuments" (2004: 383), I would like to demonstrate that a work of fiction may play an important role in forging cultural memory. Unlike fixed monuments, for example those made of stone, brick and mortar, texts may be carried through space. They may enter into completely new situations and be presented to new reading audiences. In this sense they are "portable" (Rigney 2004: 383). The more they are valued as artistic achievement, the greater their likelihood of being shared, used and re-used, not only consolidating common heritage of a given group, but also arousing interest of new groups of readers. I hope to show that James's novel displays the potential of reflexive narrative memorial by using a variety of narrative techniques and devices, chief among them being: focalization and multiple perspectives, the musical quality of its prose and its saturation with references to mass culture, and, above all, its indebtedness to the oral tradition of the Caribbean Islands. In doing so, James's novel is capable of transmitting and transforming the shared transatlantic memory of Bob Marley, the greatest reggae star of all time.

Erll (2008: 390-391) distinguishes four modes of the "rhetoric of collective memory," which are: "experiential", "mythical", "antagonistic" and "reflexive." The experiential mode represents the past as a lived-through experience, with detailed descriptions of everyday situations. The mythical mode either deals with a distant past or creates a "primordial atmosphere" (391). The antagonistic mode uses negative stereotyping and biased forms of perspective to reject a particular vision of the past and replace it with another. Finally, the reflexive mode draws attention to the act of remembering and is often based on a direct first-person narrated account of the process of recollection. It is this mode which can be recognized in the poetics of A Brief History of Seven Killings, which consists of a series of eye-witness accounts by first person narrators who recollect the events from different perspectives. Thus, James's novel revives the memory of Marley and simultaneously acts as an agent of observation and evaluation. It evokes and represents reality on multiple levels - the level of the presented world, the level of the artistic and spiritual legacy of the Jamaican musician, and the level of a multifaceted, multidimensional popular culture with its many channels of communication. The novel both implants a certain vision of the past and also opens up possibilities for the reader to read between the lines, since several theories concerning diverse instigators of the assassination attempt on Marley's life exist side by side. Moreover, as Rigney (2004: 380) argues, for a piece of narrative art to become memorable and to fix itself in the mind of the reader, it is important 
that it exhibits certain qualities, such as the writer's narrative skill, his/her ability to create interesting characters and his/her "literary expressiveness" (380), all of which are to be found in A Brief History of Seven Killings. But first, let me set the context.

\section{The context}

Nesta Robert Marley was born in the Jamaican village of Nine Miles, located in the north-central region of the island, deep in the countryside, probably on $6^{\text {th }}$ February 1945. His black mother Cedella (née Malcolm) was eighteen at the time, his white father - Norval Marley (known as 'Captain Marley') - in his sixties. Although Captain Marley 'did the honourable thing' of marrying the girl in trouble soon after learning about her pregnancy, the marriage did not last. Since the age of five Bob (or Nesta as he was then called) had no contact with his Dad, even though originally it was his father's idea that the boy should move to Kingston for a better education, which he did. Marley's teenage years were thus spent in Jamaica's capital, in the poor ghetto of Trench Town, the area commemorated in a number of songs (e.g.: "No Woman No Cry", "Trench Town Rock"). Bullied at school because of his light skin, the boy had two passions which stayed with him for life - music and football. At sixteen he wrote and recorded his first songs. It was also in Kingston that Marley formed the Wailers with Peter Tosh and Neville Livingston (Bunny Wailer). The group's career took off in the 1970s and they soon became the best known reggae singers worldwide. Although in later years the artists parted company, Bob Marley's recognition and fame went from strength to strength. With his distinctive style, politically charged lyrics and catchy tunes, with time Marley became one of the world's most influential musicians and personalities, and the first ever superstar emerging from a former colony, a cultural icon, a symbol of the Jamaican ghetto life, endlessly commercialized and merchandized. His professional activity became a springboard for advancing his creed of equality and justice, as well as his Rastafarian beliefs, while his private life, with a quick succession of love affairs, constantly spurred the ever growing media attention. In 1976 he survived an attack on his life which led to a self-imposed exile. When he died of cancer in May 1981, at the age of thirty-six, he left thirteen children by seven or eight different women (Higgins 2010: 29) and, most importantly, scores of records with a plethora of unforgettable songs whose lyrics still resonate in the most remote corners of the world - from Canada to Zimbabwe, from Sweden to New Zealand. It is not possible to give the exact count. Timothy White notes that "the Wailers have appeared on hundreds of singles, whether prerelease, bootleg, rerelease, normal release, etc. To further complicate matters, a single song could be redone an indeterminate number of times" (2006: 462). "Redemption," the final track on their album "Uprising" is believed today to be the most influential recording in the history of Jamaican music. The image which emerges from Marley's biographies 
(e.g. Salewicz 2010, White 2006) and film tributes, is of a shy person exploited and cheated by managers and record companies, a spiritual man deeply committed to his faith, a slender, modest, unassuming, talented and charismatic artist with "a disciplined approach to work" (Salewicz 2010: 102).

A Brief History of Seven Killings, noticeably based on Timothy White's Catch a Fire: The Life of Bob Marley (2006), and published in 2014, is the third novel of the Jamaican author Marlon James. It has received considerable public and critical attention as the winner of the Man Booker Prize 2015. Written as a series of interior monologues, with episodic structure, a huge cast of characters and several first person narrators, the novel depicts Jamaica in the turbulent decade of the 1970s, with the setting moved in later parts to the USA of the 80s and 90s. The starting point of the story is an attempted attack on Marley's life in December 1976 and the events leading to its execution. As the plot gradually unfolds, the reader plunges more and more deeply into a tale of political rivalry, street gangs wars, organized crime, drug trafficking, and CIA machinations. It is only at the very end, in the book's concluding section, that it finally becomes clear why a 700-page-long novel in which violence and deprivation lead to hundreds of deaths on an everyday basis is called a "brief" history of "seven" killings. Paradox and riddle - central to the Caribbean tradition of story-telling - strongly underpin the text's narrative structure, reminding us of the fictional aspect of the tale. The disclaimer stating that "all names, characters, places, and incidents either are products of the author's imagination or are used fictitiously" (no page given) is, however, countered by the book's two epigraphs: "Gonna tell the truth about it, honey, that's the hardest part" and "If it no go so, it go near so" (np). Unquestionably, many of the presented events really happened, certain prominent politicians are not only mentioned by name but were truly important players on the national arena, and the broad canvas of the story is meticulously accurate, all of which has earned James's novel the label of a "historical epic" (Armistead 2016). But the stream-of-consciousness technique of several narrative pieces, as well as long stretches of the drug-induced mumbo-jumbo of a few characters, are good reasons to undermine the veracity of the account. Marley himself is not an important character, remaining somewhere in the background. Throughout the book, he is referred to as the "Singer" and only once, randomly, his real name is used. Yet, his identification as the "reggae superstar of the world" (xi), his true Kingston address of 56 Hope Road, numerous details of his musical career and personal life, leave no doubt about the narrative's fidelity to truth.

The attack on Marley took place on the 3rd December 1976, a few weeks before the general election (to be held on the $15^{\text {th }}$ December), during the country's State of Emergency, at the time when Jamaica was on a brink of a civil war and when the political scene was deeply polarized between two rival parties and their supporters and goons. At the one extreme was the PNP (People's National Party), the left-wing party ruling since 1972, under Michael Manley, at the other - its political opponent, Jamaica's Labour Party under Edward Seaga, trying to seize the power. Michael Manley, the country's prime minister, was perceived as 
dangerously inclining towards socialism and likely to follow in the footsteps of Fidel Castro, which deeply worried the USA. Seaga, named in graffiti "CIA-ga" (Goldman 2006), was secretly supported by the US secret service. Both parties used street gangs for protection and as enforcers. Marley, who tried to remain apolitical and not aligned with either faction, was, however, widely believed to support the Prime Minister in office, who not only gave the singer some land, but also promised to legalize marijuana (Salewicz 2010: 190). Moreover, a free concert by the Wailers "Smile Jamaica", planned for the $5^{\text {th }}$ December, was originally designed to take place in front of the prime minister's official residence. The location was changed on Marley's insistence, but gossip spread, making him bitter. Allegedly, he was heard to say "dem want to use me to draw crowd fe dem politricks" (Goldman 2006). The assailants arrived at the singer's premises in two cars, got passed the security and fired M16 automatic rifles at anybody in sight. The bullet shot at Marley creased his breast just below the heart and "drilled deep inside his arm" (White 2006: 289). It was never removed.

Clearly, Marley had many enemies. They included the supporters of the JLP who wanted to have a new government, people who believed the singer to cooperate with gangsters and especially their powerful "ranking dons", as well as those who despised all Rastafarians. There were among Marley's opponents also people who considered him a traitor, since "Rasta not supposed to bow" (James 2015: 27). Additionally, it was common knowledge that a certain horse-racing scam was concocted on Marley's premises and although he himself did not participate, he was held responsible. Crucially, Marley's adversaries were also the people who considered his music dangerous. In 1976 he was at the height of his career, recognized as "the biggest musical superstar in the Third World" (White 2006: 275), and the revolutionary ideas of his lyrics found fertile ground especially among his international followers. Some songs, like "I Shot the Sheriff", "Burnin' and Lootin"" and "Get Up, Stand Up", were believed to reflect the spirit of the Black Power movement (White 2006: 261). There is a clear suggestion in the novel that the Singer received threats and warnings issued by the American embassy in Kingston, famously full of the CIA operating officers. The above, as well as many details concerning Marley's daily habits, are supported by his biographers' accounts (White 2006, Salewicz 2010).

\section{James's novel as a "portable textual monument"}

Ann Rigney's concept of a literary text as a portable monument not only foregrounds the role of literature as an agent of remembrance. By emphasizing the relationship between history and fiction, as well as the key role of discursive practices in making sense of the past, it offers a tool to link cultural memory with "fictionality and poeticity" (Rigney 2004: 361). As she notes, contemporary approaches to cultural memory imply recognition of "the multiple ways in which images of the past are communicated and shared among members of a commu- 
nity through public acts of remembrance and through publicly accessible media" (366).

In A Brief History, images of the past are communicated to the reader via interior monologues of characters/narrators, most of whom had some contact with the Singer. Specifically, the arguments and reasoning of Marley's opponents are unambiguously articulated in the first section of the book, "Original Rockers," which depicts the situation in Kingston in December 1976, with the events leading to the attack and also gives voice to the principal narrators of the story, some of whom are the would-be assassins: Josey Wales, Demus and Bam-Bam. Their interior monologues are in large parts addressed to Marley, so the Singer is not only somebody who preoccupies their thoughts but also plays the part of an agent in an imagined conversation. The main architect of the attack, Josey Wales, is the novel's most wicked character, a psychopathic murderer who masterminds drug business in Jamaica, Miami and New York, and participates in smuggling weapons to the island. When he accepts the CIA's proposition to kill Marley, he wants to prove his power and future potential as "the don of all dons" (James 2015: 44), knowing at the same time that he is smart enough to outwit the American agents once they decide to eliminate him. Besides, he despises the Singer. Generally speaking, he hates Rastafarians because they "won't comb their hair and recognize Jesus as their lord and savior" (40), but his particular reason to hate Marley is the fact that the Singer speaks Jamaican patois, the language of the uneducated masses. He remarks: "To think you have all this money, all these gold record, have lipstick print on your cocky from all sort of white woman, and that is how you talk? If my life is juss fi mi, mi no want it? Then give it up, pussyhole, I coming right 'round there to take it" (42).

The remaining attackers are enrolled in the plan partly through Josey's manipulation, partly through their drug addiction, partly through their misunderstanding of the situation. The reasons are different. For Bam-Bam, an orphaned teenage gang member, Marley is a schemer and hypocrite who works for western record companies, co-operates with Babylon and mingles with white performers. Bam-Bam's thoughts reflect disappointment and hostility because Marley is no longer a man from the ghetto but "the sufferah who turn big star" (34), the man who "tramp through Babylon" (34). And so Bam-Bam does not listen to him, he listens to songs "from people who can't pay for no guitar and don't have a white man to give it to them" (37). Furthermore, Bam-Bam knows that Marley is rich and the fact that he does not live in luxury is interpreted as a way of cheating: "your truck look beat up and not what we expect and that make me angry because nothing worse than when a man have money and pretend he don't have none like acting like you poor in some sense" (34). Importantly, Bam-Bam also believes that Marley keeps contact with the people responsible for his parents' death, which gives him a personal motive to kill the Singer.

Seemingly, it is personal vendetta that lies at the root of Demus's wish to kill Marley. Demus is one of the gangsters who participated in the horse-racing scam and was promised a substantial amount of money for kidnapping a jockey and 
forcing him to lose three races. Since not a single dime out of some 40000 American dollars has come his way, he feels wronged. But his monologues reveal a more complicated attitude. In the past, Demus was a victim of police brutality which caused severe damage to his body. Drugs, which alleviated pain, led to addiction. He reminisces:

When the pain was so bad that only strong weed could help me, the only other thing that help was the Singer. [...] Is not that music take away the pain, but when it play I don't ride the pain, I ride the rhythm. But when Josey Wales tells me last night who we shooting up I go home and vomit. [...] Me is a wicked man, me is a sick man, but me would never join in this if I did know that he want to rub out the Singer. This hurt me brain worse than anything ever hurt me before. [...] I know God coming to judge me. Nobody who kill a police going to hell but is something else to kill the Singer (56-57).

Yet, he will shoot Marley. Demus craves cocaine and he will do anything to obtain "a line," and as a rank-and-file gang member he knows better than to oppose Josey Wales, even though he sees through his smooth talk:

I let Josey Wales tell me that the Singer is a hypocrite, and he playing both sides taking everybody for idiot. I let Josey Wales tell me that he have bigger plans and is high time we done be ghetto stooge for white man who live uptown and don't care about we until election time. I let Josey Wales tell me that the Singer is a PNP stooge who bow for the Prime Minister. I let Josey Wales tell me to shoot up three more line and I won't care who (57).

What the monologues of the three attackers share is a mixture of fact, gossip and opinion. The reader learns about Marley's looks and everyday habits, his small posture: "you was always small" (33), and a strict ital food diet. There is evidence of the Singer's charity and the financial support given to the Kingston's poor: "by now you feeding three thousand people, which everybody know but nobody talk about" (34), as well as some anti-Wailers conspiracy by the local radio stations: "They never play him on the radio" (56).

The same intermingling of objective information and hearsay is also to be found in the monologues of other narrators: American journalist Alex Pierce, CIA agent Barry Diflorio, one of the dons of the gangster world who happens to be Marley's friend (Papa-Lo), and a black girl who was Marley's one night stand (Nina Burgess). Ranging from objective interest to friendly feeling mixed with tender love and genuine admiration, and sexual fascination coupled with some expectations of help, they provide a counterbalance to the murderers' disclosures. They reveal the Singer's strict daily routine and provide comment on his international fame and the popularity of reggae music worldwide, highlighted by its strange non-existence on Jamaican radio. Marley emerges from these sections as 
a charismatic artist whose music inspires large audiences but who has never lost touch with his home turf, a strongly emotional person who has opened his house to all kinds of people, many of whom abuse his trust, as well as a generous provider of very real material support through financing the education of hundreds of Jamaican children. He is also a sex symbol compared to Byron (144) and "a black lion" (31), surrounded by beautiful women, and a trustful friend with whom one can share a joint (or a chalice) and talk about life, an idol and a Jamaican icon figure universally acknowledged, somebody who in the time of cut-throat competition and skyrocketing crime rate should be safe, since he is, and should be, above all "politrics": "everybody in Copenhagen City, the Eight Lanes, Jungle, Rema, uptown and downtown know that nobody ever pull gun on the Singer" (26). At one point Papa-Lo declares: "Me love that man to the max. Me would take the bullet for the Singer. But [...], me can only take one" (27). At the moment of his death, his thoughts go to the Singer and he has a prophetic vision of Marley's cancer treatment: "... the Singer have no hair anymore the Singer on a bed the Singer getting a needle from a white man who have a German Hitler sign burning in him forehead" (360). His body riddled with dozens of bullets, feeling how he changes from a living man into spirit, Papa-Lo wishes he could save the Singer, not himself.

[M]e neck speaking blood me mouth can't open the angel of death sitting on the Singer shoulder [...] and me rising higher and higher but me still on the road [...] if I shout loud enough cut off the toe skip cut off the toe don't listen to no bombocloth idiot Rasta who just sucking your blood through the chillum pipe cut off the toe and don't make no Nazi touch you (361-362).

Verified against historical information, especially Bob Marley's detailed and thoroughly researched biographies, apparent gossip and hearsay presented by the characters-narrators sticks to evidence, while variously scattered bits and pieces of his life and career create a composite picture of a music star. Arguably, Marlon James's reliance on 'historical truth' strongly underpins the story and the developments of the plot are borne out by historical accounts. In 1976, as in A Brief History of Seven Killings, Marley is a public figure with a status of a celebrity, caught in politics against his will and brushing shoulders with the underworld, a polarizing person in the Jamaican society who has both devoted followers and sworn enemies. He is more of a symbol than a flesh-and-blood poet and musician, in the words of Alex Pierce: "[a]n allegory kinda" (82). And although much more attention of the novel is given to the characters narrating the tale than to the Singer himself, his presence fills the book in diverse ways. Marley becomes a point of reference in a significant number of monologues, his angry lyrics pulsate in the story, and his artistic achievement receives full recognition and tribute. People in the ghetto sing that they are "tired of the shitsem and the ism and schism" (36); women who do their washing in government yards cry out that it is "high time the big tree meet the small axe" (36), and "boys in the street sing them belly full but 
them hungry" (82). The power and appeal of Marley's reggae is deeply felt and the evolution of his art reflected in Papa-Lo's worry:

And congo bongo I? 'Natty Dread' congo bongo I. I mean, I get 'I Shot the Sheriff,' that's a metaphor, right? Ism and Schism? What I want to know is what happened to the man who sung sweet songs like 'Stir It Up.' [...] What happened to the love everybody vibes? 'Burning and Looting'? Is that like 'Dancing in the Street'? You know, angry nigger music (139).

Numerous allusions to Marley's songs and the musical quality of the novel's discourse create the potential of a sensuous experience for the reader. While reading the novel, the reader is encouraged to "remember" Marley bodily - through sounds, rhythms, vibrations and vibes. Memory has often been viewed as a bodily sensuous phenomenon (Landsberg 2004: 112; Connerton 1989: 73). The kind of bodily memory as a somatic experience of the reader whose sense of sound is involved, although the reader could not personally live through an event described, has been called by Alison Landsberg "prosthetic." Memory becomes physically inscribed on the body as if through a phantom limb. The act of reading creates a "transferential space," where the reader enters into a relationship with past events with which he/she did not have direct connection. James's prose produces a sensuous recall also through the appeal to extra-textual familiarity with tunes and lyrics. On the arena of the international musical scene, Marley is one of many artists who recorded and performed in the seventies and whose songs or names are mentioned in the book, also in the novel's paratext. All titles of the five parts use the song titles by various musicians. By alluding to the constant presence and importance of rock and pop in Jamaican life, by speaking through music in his rhythmical prose of markedly oral quality, Marlon James moves the novel to another plane, the aural level, where the written word is one of many channels of communication, not necessarily the most important.

The use of multiple narrators with their one-off spontaneous accounts of events, which gives the novel a quality of an oral narrative, simultaneously links the practice of recalling with the Caribbean vernacular tradition of story-telling. Studies that focus on the difference between the scribal and the oral, such as Goody's The Interface Between the Written and the Oral (1993), Havelock's The Muse Learns to Write (1986), and Ong's Orality and Literacy (2002), tend to locate orality in ancient times. Thus, the novel's employment of aspects of oral narrative may be seen as a strategy pointing to historical continuity, revealing at the same time the present as steeped in the past. Referring to Caribbean literature, Carolyn Cooper stresses "the oral/scribal literary continuum" (1995:34) as a way of continuing tradition in a novel form. James's multiple narrators can be seen as folk story-tellers whose role in a community has been, through centuries, to pass on values and beliefs, forge collective memories and provide means of a group's identification and self-definition. Verbal performance and discourse, usually associated with the common man, might also provide a venue for building collec- 
tive self-esteem and remembering. James's use of such literary devices which characterize the oral epic can be detected both in his employment of specific metaphysical framework dominated by a powerful voice of a ghost (Sir Arthur George Jennings's narration), as well as in his use of several technical aspects of oral craft, for example his incorporation of proverbs, rhetorical questions, instances of audience participation, code-switching, jokes, puns and riddles, and, most importantly, the use of monologue as a major form of the novel's discourse.

Describing the language style of oral performance, Walter Ong notes that it is "additive and aggregative" rather than "subordinative or analytic" (36-38). A three-part pattern of listing is frequently used by James, as for example in: "the oma has hopped, skipped and jumped from your foot to your liver, lungs and brain" (435); or: "You wake up and smell sex, smoke and whiskey" (434); or: "nobody listens, nobody looks, nobody comes" (434). Such instances enhance the rhythmic prosody of the monologue, adding to its musical quality and heightening its aural appeal. A few examples of some most notable features of an oral epic may illustrate the point. We find rhetorical questions in: "How do you bury a man? Put him in the ground or stomp out his fire?" (599) and repetition in: "Death makes you cough, piss, death makes you shit, death makes you stink from inside vapors" (111). The sentence "Now something new is blowing" (430) is repeated nine times within the space of seven pages. A powerful instance of repetition, enumeration, and additive style is provided by Sir Arthur's final words in his last monologue, meant as a tribute to Marley:

[I]n another city, another valley, another ghetto, another slum, another favela, another township, another intifada, another war, another birth, somebody is singing Redemption Song, as if the Singer wrote it for no other reason but for this sufferah to sing, shout, whisper, weep, bawl, and scream, right here, right now (601)

The above fragment reads like oratory, a speech from the pulpit, meant to embrace millions of listeners, inclusive in its address across the depth and variety of experience, geographical breadth and scope, magnificently suggestive in its evocation of the rising degree of sound ("sing, shout, whisper, weep, bawl, and scream"). It highlights the universality and power of Marley's art which reached above the social and continental divides, and accentuates its spiritual potential, its ability to simultaneously address an individual and the masses, forging unity in the face of injustice and deprivation. Marley is and will be remembered across the globe. The above quoted closing paragraph of Sir Arthur's speech fulfils the role of a metaphoric full stop concluding a long tale, a tale which started with a clearly made demand: "Listen" (1).

"Listen" (1) is the novel's very first word, an unequivocal implication that the whole story is in fact told to an audience, an audience whose participation in the act of story-telling and thus an act of remembering and recalling is crucial. The expected involvement and reciprocity of the listener is constantly emphasized and 
the reader's awareness of being drawn into an act of oral performance strongly suggested by James's use of the formulaic expression "this is a story of ...", with precise information about the theme and content of the tale to follow, included in Sir Arthur's first monologue: "This is a story of several killings, of boys who meant nothing to a world still spinning..." (3). A direct appeal to the listening audience with a simultaneous stress on an act of speaking, and the reader/listener co-presence, markedly feature in the monologues of other characters, for example in Papa-Lo's appeal: "Listen to me now" (23), "So look at me. See all this?" (23).

Thus, we can recognize in A Brief History distinctive strategies that transmit memories. The use of multiple first-person narrators with their different points of view creates an opportunity for the reader to "re-live" numerous scenes over and over again. First person accounts, by their virtue of being the acts of witnessing and reporting, successfully diminish the distance between the reader and the presented world. They heighten the impression of authenticity and faithful recall. The use of focalization creates an illusion that diverse incidents of the plot are not merely recorded but actually "remembered." The result is that they "stick in the mind" (Rigney 2004: 381) and become memorable. Another important technique, mentioned earlier, the use of frequent, insistent repetition, makes the sound reverberate like a drum-beat and imprint itself on the reader's/listener's memory as if automatically.

With the novel's authorial absence, Marley's figure is always characterized indirectly, in other characters' voices. Thus, the Singer's sporadic utterances reach the reader only when quoted by someone else. The key event - the moment of the attack - is recounted by several people. Repeated many times, Marley's words, few as they are, echo strongly, acquiring the attribute of a religious pronouncement. This, in turn, makes them more "memorable." The sentence spoken at the time when the bullet is aimed at Marley's heart is repeated three times. All Marley says is "Selassie I Jah Rastafari" (240, 347, 391). As Alison Landsberg (2004: 136) argues, "repetition $[\ldots]$ has a generative quality and does not simply reproduce the same. [...] repetition actually produces difference." This difference rests on the singularity of the speaker and the context.

The fact that Marley survives the attack is interpreted as proof of his divinity. $\mathrm{He}$ is compared to Jesus Christ, by both Demus and Bam-Bam. Demus declares: "I goin' be one of the man who kill HIM which is like the man who kill Jesus" (246); “...them people don't know what it really mean to kill Jesus fucking Christ" (249). "The sun send demons after me, just as he send demons after Judas Iscariot" (252). While Bam-Bam, addressing Marley in his interior monologue and recalling the shooting says:

You look at me

And I want you to shout and scream and sniff and tear

Piss your pants, jerk and fall

But you just look, you didn't blink

And I and I 
BamBam

Jah Rastafari shot you in the heart

You call out Selassie (241).

And later:

You drop your grapefruit and look straight at me

Like Jesus telling Judas

To get it done already

Me is you, Pilate me is you, Roman soldier (242).

When the information reaches the public that the Singer will perform in Smile Jamaica concert as planned, Bam-Bam thinks: "He beat death like Lazarus, like Jesus" (255); "the Singer is Jesus" (257). "Nobody can kill the Tuff Gong. So Jah say" (259-260). And during the concert he observes: "You point to your wound like Jesus pointing to his side to show the work of the spear" (261).

However, the comparison to Jesus does not come for the first time at the moment of Marley's appearing on stage two days after the attack. Already on the first page of Bam-Bam's narration in part I, we read: “...we watched your big house on Hope Road for days now, and at one point you come to talk to us like you was Jesus and we was Iscariot and you nod as if to say get on with your business and do what you have to do" (7). The above remark provided at the outset of the tale accentuates important layers of meaning. It interconnects guilt with doom and introduces the spiritual aspect of Marley's presence - not as a musician and famous performer, but as a deeply devout follower of Rastafarianism, somebody ready to die, if fate decrees so. The mention of Judas Iscariot as a traitor is but one example of the book's rich intertextuality. Biblical references abound in the novel and the characters use Biblical themes, motifs and terminology freely. In Jamaica, the Bible is the most often quoted book and in the past was "the only book with which the masses of Jamaicans were acquainted" (Edmonds in Murrell 2000: 10). As Murrell notes, in the Anglophone Caribbean, "the Bible does not only provide a basis for religious faith and practice, it is also an essential part of public education and political practice" (Murrell 2000: 10).

The image of Marley as Christ-the-Redeemer re-enters the story when it is revealed that the Singer has pardoned one of the attackers. When Heckle throws himself at his feet begging forgiveness, the Singer does so and offers him shelter and protection, which provokes a comment from Papa-Lo: "Maybe he really is like a prophet. Me don't even know if Jesus would ever do such madness" (421). The above quoted comparisons add to the impression that Marley is not treated solely as a historical character in a work of fiction strongly based on facts. They bring to mind the status accorded to him not as to the reggae star but an important member of the Twelve Tribes of Israel Rastafarian group. In many Rastafarian communities Marley was (and still is) believed to be a prophet (Douglas and Boxill 40). However, we should refrain from seeing Marley as unequivocally 
elevated to the status of a divine force. Although his sparse verbal messages might be interpreted as proof of his nebulous rather than material existence, like his declaration: "The devil no got no power over me" (88), it must be remembered that in the culture of the Caribbean Islands the dividing line between religious and secular is blurry, as evidenced in the biblical stories constantly re-appropriated and re-imagined outside organized religion to suit a specific historical context and thoroughly enmeshed in popular culture. They are refracted through indigenous religions, Rastafarian beliefs and everyday life. Wainwright observes that traces of biblical text "function within contemporary literary and visual arts, music and other multimedia" (Wainwright 2010: 3). Thus, the image of Marley as a prophet or god, a heroic and divine presence unafraid of death is on a par with images of numerous "heroes" from American films that abound in the novel. (The arch-villain's sobriquet is borrowed from the American movie "The Outlaw Josey Wales", where the title role is played by Clint Eastwood).

The portrayal of Marley which arises from conflicting opinions of his admirers and opponents (including his attackers), the portrayal of him both as a person and a cultural icon, a Jamaican of low origin raised in the ghetto of Trench Town, who arouses hostility and admiration, hatred and love, as well as a celebrity who achieved international reputation, is supplanted by a more detached comment from the most unusual narrator, Sir Arthur George Jennings, the ghost of a murdered politician. The emotionally charged opinions of Marley's enemies and followers are thus complemented by the account provided by a spirit who, being invisible, may witness events and conversations not related by other characters. Sir Arthur is present at crucial moments, such as the deaths of Marley's assailants and also the death of Marley himself many years later. It is he who reveals numerous facts of the Singer's life that are only recognized by those who know his biography. With his power to know past and future, with his ability to transcend time and space, Sir Arthur presents a condensed account of Marley's life, career, his final years and his funeral. As other narrators, he frequently addresses the Singer, but the tone of the speaking voice constantly changes, as do the addressees. Such sentences as: "You are in the studio" (431); "You're playing football in Paris" (431); "You are in London" (432); "You are in Miami" (432) "I see you whirling like a dervish, under the rhythm and above it, jumping up and down the stage, always landing on your Brutus toe" (431), suggest close following of the events in Marley's life. They relate the quick progress of cancer, various medical therapies and hospital treatment - in Mexico, where they "couldn't save Steve McQueen" (435), and in a Bavarian clinic of Josef Issels. Technically, they point to the status of an eye-witness who is immortal and whose remembering is to be doubly trusted.

Through Sir Arthur's narration, Marley's personal story, which unfolds against the backdrop of his international tours - Paris, London, Miami, New York, Pittsburgh - becomes intertwined with the events taking place in Kingston, as if the Singer's destiny could never be disentangled from his Jamaican home, as if he was "a living breathing sufferah who is always where he's from no matter where 
he's at" (82). His final months - after his collapse in Central Park - are recounted from the perspective of a judging witness and somebody who, being dead himself, understands the solitude of death. The events in Jamaica, on the other hand - the ever-growing violence of street gangs and the police, the despair and destitution of ghetto dwellers - presented in multiple voices. The multiplicity of voices creates a social framework for memories of individual characters, providing a means of confrontation and confirmation. Individual memory works through reminiscing and recollecting, but needs other people for the recollections to be borne out. The presence of others as witnesses to individual memories opens the possibility of different individuals 'remembering' events reconstructed and 'remembered' by others. In the words of Rigney: "Through repeated acts of communication, individual memories of particular events tend to converge with those of other people as these circulate and spread in the public sphere. This means, among other things, that the memories which individuals have of events in which they themselves participated become mediated by other people's memories of the same events as these are expressed, and thus stabilized" (366).

In Sir Arthur's monologues, as well as in the monologues of the would-be-assassins, the second person pronoun "you" as a form of address and interpellation performs a double function. On the one hand, it establishes direct contact with the reader/listener, commensurate with the form of a publicly told tale. On the other hand, it opens the possibility of imagining Marley as an interlocutor, telling him things he might have been unaware of: "A plastic machine with veins pushed into your skin, doing all the living for you [...]. In New York City and in Kingston, both skies blazing bright with noon white, thunder breaks out and a lightning bolt slashes through the clouds. Summer lightning, three months too early [...] You're gone" (436).

It is in Sir Arthur's narrative voice, the voice of an ex-colonizer and a white man, that the greatest tribute to Marley's accomplishment is expressed. Sir Arthur knows the future, he can assess the legacy and spiritual power of the Singer to inspire and give hope, to believe. Quoted earlier, Sir Arthur's last words are an acknowledgement of the popularity of Marley's art among the dispossessed, and proof that the fire ignited by his songs couldn't be "stomped out" (599). Marley is dead but his music lives on.

\section{Concluding comments}

If, as argued above, literature can constitute a medium of memory, and if Marlon James's A Brief History of Seven Killings is read as an act of remembrance, then we may ponder the text's method of appropriating the past. Jonathan Crewe (1999: 76) states that books are "bearers and construction sites of cultural memory" simply because they transmit and implant memories in their readers. But, as Rigney (2004: 390) stresses, the role of literary texts in the process of forging memories is dependent on their "fictional and poetical qualities" on the one hand, 
and on their longevity on the other, because "literature does not have a single pregiven role in memorial dynamics; nor do literary works have only one cultural afterlife" (2004: 390). The poetical qualities of James's novel, with its technique of focalization, polyphonic narration, musical quality of the language, strong emotional component, appeal to affect, use of the oral tradition of the Caribbean Islands, and rich intertextuality, add to its memorability. As for longevity, it is too early to tell.

The memory of Robert Nesta Marley transmitted by James's novel is the memory of a legend and symbol, an icon of the Jamaican contribution to world culture. The Singer is not a central character of the story and the author's attention is apportioned much more lavishly on themes and issues not showing direct connection with his life. James's portrayal of the reggae superstar, seemingly, recycles many wellknown and some less well-known facts, highlighting the artist's international status and his ambivalent position at home. Yet, fidelity to truth cannot be considered Marlon James's major accomplishment. Much more significantly, remembering Marley consists in inscribing his presence into the social fabric of the Jamaican society. The novel's setting, with very vivid descriptions of poverty, injustice and violence gives credibility to Marley's voice as the spokesman of the disadvantaged and marginalized. Marley is part of the milieu; the narrativization of his life in multiple voices endows it with richness and ambiguity. Literature as a vehicle of collective memory may "elicit different modes of cultural remembering" (Erll 2008: 390), since the uses of the past made by authors are determined by historical contexts and social consciousness. Marley's presence in the novel is both real and elusive - real in the mundane details of his early-morning exercise and his diet, elusive in the musical rhythmic quality of the language and the urban legend.

Marley in James's novel is both a Jamaican sufferer who achieved fame, and a national icon larger than life. Even the arch-villain Josey Wales admits at the end of his life that he wished the Singer had died in a different way, without the pain and anguish of his final months. Comparisons to Christ, the mention of supernatural occurrences at the time of his death, his symbolic presence during the Rasta Avengers kangaroo court, the inclusion of a ghost among the narrators - all of the above point to the immaterial, spiritual aspect of Marley's contribution to Jamaican (and international) culture. As an artist, he is enmeshed in the rich fabric of the novel's intersemiotic level, where music coexists with popular Hollywood films and detective serials, and where the Biblical stories counterbalance ancestral beliefs in duppies and duppy-conquerors. Thus, his presence raises the novel to a higher level than that of a crime story and a political tale. His life is both symptomatic and singular. When Sir Arthur's ghost observes: "They give the Singer an honour on his deathbed, the Order of Merit. The black revolutionary joins the order of British Squires and Knights, Babylon in excelsis deo" (599), the irony of the situation hits the reader as an example of a proverbial conspiracy of the white man to deprive the black man of any power through incorporation.

Artistically, A Brief History is an extremely interesting literary achievement. It is a novel firmly situated within the vernacular tradition of the Caribbean Islands, 
bringing together orality and literacy, as well as the African and the European heritage, pointing to Jamaica's vibrant and rich culture with its many voices and beliefs. It seems highly appropriate that Bob Marley re-captures international attention through a very well articulated and commercially successful work of art. Marlon James's novel does more than perpetuate the memory of the Jamaican super star. By making him a figure of the background rather than a central character, James foregrounds the destiny of many unknown Jamaicans whose lot was propelled by the social and political events of the time. As a "portable textual monument" (Rigney 2004: 383), successfully promoted through its international recognition and reaching audiences across continents and generations, $A$ Brief History of Seven Killings creates an opportunity to remember Marley through remembering Jamaican past in the turbulent decades ending the twentieth century. It proves that oral memory effectively enters the mnemotechnics of the written word and record, and enters the transatlantic public sphere. By being transmitted and circulated, it stamps its presence in a public memorial space.

\section{References}

Armistead, Claire (2016) The Sellout rips up rulebook for what award-winning fiction looks like. The Guardian, 26 Nov. 2016. Accessed on 26 Nov. 2016.

Barnett, Michael (ed.) (2012) Rastafari in the New Millennium: A Rastafari Reader. Syracuse: Syracuse University Press.

Berliner, David (2005) The abuses of memory: Reflections on the modern memory boom in anthropology. Anthropological Quarterly 78(1),197-211.

Connerton, Paul (1989) How Societies Remember. Cambridge: Cambridge University Press.

Cooper, Carolyn (1995) Noises in the Blood. Orality, Gender, and the 'Vulgar' Body of Jamaican Popular Culture. Durham: Duke University Press.

Coser, Lewis A. (1992) Introduction: Maurice Halwachs 1877-1945. In: Halbwachs, Maurice (ed.) On Collective Memory, Chicago: University of Chicago Press, 1-34.

Crewe, Jonathan (1999) Recalling Adamastor: Literature as cultural memory in 'White' South Africa”. In: Bal, Mieke, Crewe, Jonathan and Spitzer, Leo (eds.) Acts of Memory. Cultural Recall in the Present, Hanover, NH: University Press of New England, 75-86.

Douglas, Edward Te Kohu and Ian Boxill (2012) The lantern and the light. Rastafari in Aotearoa (New Zealand). In: Barnett, Michael (ed). Rastafari in the New Millennium: A Rastafari Reader. Syracuse: Syracuse University Press, 35-65.

Erll, Astrid (2011) Memory in Culture. Basingstoke: Palgrave Macmillan.

Erll, Astrid and Ann Rigney (2006) Literature and the production of cultural memory: Introduction. European Journal of English Studies 10(2), 111-115.

Goldman, Vivien (2006) Dread, beat and blood. The Guardian, 16 July 2006. https://www.theguardian.com/music/2006/jul/16/urban.worldmusic. Accessed on 26 Oct. 2016.

Goody, Jack (1993) The Interface Between the Written and the Oral. Cambridge: Cambridge University Press.

Halbwachs, Maurice (2007) The collective memory. [trans. Francis J. Ditter, Jr. and Vida Yazdi Ditter]. In: Rossington, Michael and Anne Whitehead (eds) Theories of Memory: A Reader, Edinburgh: Edinburgh University Press, 139-143.

Havelock, Erick A. (1986) The Muse Learns to Write. Reflections on Orality and Literacy from Antiquity to the Present. New Haven and London: Yale University Press. 
Higgins, Dalton (2010) Fatherhood 4.0. iDad Applications Across Cultures. Toronto: Insomniac Press.

http://www.bobmarley.com/history

Huyssen, Andreas (1995) Twilight Memories: Marking Time in a Culture of Amnesia. London and New York: Routledge.

Huyssen, Andreas (2000) Present pasts: Media, politics, amnesia. Public Culture 12(1), 21-38.

James, Marlon (2015) A Brief History of Seven Killings. London: Oneworld Publications.

Landsberg, Alison (2004) Prosthetic Memory: The Transformation of American Remembrance in the Age of Mass Culture. New York: Columbia University Press.

Murrell, Nathaniel Samuel (2000) Dangerous memories, underdevelopment and the Bible in the colonial Caribbean experience. In Gossai, Hemchand and Nathaniel S. Murrell (eds.) Religion, Culture and Tradition in the Caribbean. New York: Palgrave, 9-35.

Ong, Walter J. (2002) Orality and Literacy: The Technologizing of the Word. London and New York: Routledge.

Rigney, Ann (2004) Portable monuments: Literature, cultural memory and the case of Jeanie Deans. Poetics Today 25(2), 361-396.

Salewicz, Chris (2010) Bob Marley.The Untold Story. London: Harper Collins.

Wainwright, Elaine M. (2010) Introduction. In: Culbertson, Philip and Elaine M. Wainwright (eds.) The Bible in/and Popular Culture. A Creative Encounter. Atlanta: Society of Biblical Literature, $1-9$.

White, Timothy (2006) Catch a Fire. The Life of Bob Marley. London, New York, Sydney: Omnibus Press.

Whitehead, Anne (2009) Memory. London and New York: Routledge.

Winter, Jay (2001) The memory boom in contemporary historical studies. Raritan 21(1), 52-66.

Anna Maria Tomczak is Associate Professor at the Institute of Modern Languages, University of Białystok, where she teaches British Cultural Studies. Her research interests include memory studies and post-colonial literature. She is the author of Reading Class: Nonverbal Communication as a Reflection of Middle Class Attitudes and Behaviours in Selected Novels of Iris Murdoch (2009) and Cultural Memory and Food: South Asian Diasporic Fiction (2012).

Address: Dr hab. Anna Maria Tomczak, Institute of Modern Languages, University of Białystok, ul. Liniarskiego 3, 15-420 Białystok, Polska. [email: atomczak@uwb.edu.pl] 